\title{
Discovery of the mandible of a young child in a Gravettian level of Gargas cave (Hautes-Pyrenees, France)
}

Pascal Foucher, Cristina San Juan-Foucher, Dominique Henry-Gambier, Carole Vercoutère and Catherine Ferrier

\section{(2) OpenEdition}

\section{Journals}

Electronic version

URL: http://journals.openedition.org/paleo/2472

DOI: $10.4000 /$ paleo.2472

ISSN: $2101-0420$

Publisher

SAMRA

\section{Printed version}

Date of publication: 15 December 2012

Number of pages: $323-336$

ISSN: $1145-3370$

\section{Electronic reference}

Pascal Foucher, Cristina San Juan-Foucher, Dominique Henry-Gambier, Carole Vercoutère and Catherine Ferrier, "Discovery of the mandible of a young child in a Gravettian level of Gargas cave (Hautes-Pyrenees, France) », PALEO [Online], 23 | 2012, Online since 18 June 2013, connection on 26 July 2020. URL : http://journals.openedition.org/paleo/2472 ; DOI : https://doi.org/10.4000/paleo 2472

This text was automatically generated on 26 July 2020.

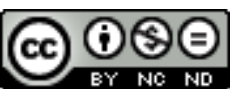

PALEO est mis à disposition selon les termes de la licence Creative Commons Attribution - Pas d'Utilisation Commerciale - Pas de Modification 4.0 International. 


\title{
Discovery of the mandible of a young child in a Gravettian level of Gargas cave (Hautes-Pyrenees, France)
}

\author{
Pascal Foucher, Cristina San Juan-Foucher, Dominique Henry-Gambier, \\ Carole Vercoutère and Catherine Ferrier
}

\section{1 - Introduction}

1 Renewed excavations have been carried out in the Pyrenean site of Gargas Cave since 2004, renowned for its abundant rock art (fig. 1). These excavations take place a full century after the last archaeological research conducted at the site by Cartailhac and Breuil in 1911 and $1913^{1}$.

2 The main aim of this operation is to establish a detailed stratigraphic sequence for the site (Foucher et al. 2008c) and to update data from the Cartailhac-Breuil excavations (Breuil, Cheynier 1958). In time, this information will contribute to a regional synthesis of the Gravettian in the southwest of Europe (Foucher 2004, 2006 and in press; Foucher et al. 2008b; Foucher et al. 2011; San Juan-Foucher 2011 and in press).

3 This renewed fieldwork also addresses wider issues including the reconsideration of the Cartailhac-Breuil collections and an approach integrating the dual function of the cave as both a rock art site and habitat. In this way, we wish to gain a better understanding of the functional, spatial and chronological characteristics of the site as well as site use by the authors of the rock art (Foucher et al. 2007, 2012).

We drew up an overview of historic excavation data in order to orient our choice of excavation zone (Foucher et al. 2007), and then proceeded to dig three excavation zones in the lower Gargas cave (fig. 2). The first zone (GES) is located just beside the Cartailhac-Breuil excavations, in the outer part of the talus cone which obstructed the prehistoric entrance; the second (GPO) is in the interior zone of this scree, about $15 \mathrm{~m}$ 
away from the first, in a room corresponding to the prehistoric entrance; the third (GPA) is in the center of Room I, nearer to the wall with the painted hands and just beside the second Cartailhac-Breuil excavation (Foucher et al. 2008c; Foucher, San JuanFoucher 2011, dir.). The child's mandible was discovered in this last excavation zone.

\section{2 - Localization and sedimentological context of the discovery}

\section{a - Topographic position of the GPA excavation zone}

In order to define the stratigraphic relations between the habitat zone excavated by Cartailhac and Breuil and the wall painted with the "large hand mural", we opened a new excavation sector (GPA) in the central zone of Room I in 2009 (fig. 2 and 3). In this part of the cave, the slightly sloped floor (about $2^{\circ}$ ) of the Column Gallery, which leads into the deep part of the cave, meets the subhorizontal floor of Room I. Water, supplied by infiltrations from ceiling fissures, and the sloped floor of the gallery are responsible for the development of a succession of stepped gours which are active after heavy rains.

6 The GPA excavation zone is at the foot of a large stalagmite, prolonged by a stalagmite floor with a tilt of about $30^{\circ}$ (fig. 4). Half of the base of this stalagmite was ripped apart by past excavators in order to reach the Gravettian level and the rest is partially undermined by those excavations. This zone is beside one of Cartailhac and Breuil's excavation test pits, but the visible excavation traces are probably those of later anonymous excavators. At present, under the stalagmite, we can see residual plating of black sediment, rich in archaeological material of all kinds (burnt bones, varied faunal remains, flint flakes, etc.) as well as a pebble formation resulting from karstic alluviation.

\section{b - Sedimentological description of the test pit GPA}

Layer 1: stalagmite floor (with a thickness varying between $2-3 \mathrm{~cm}$ and $20 \mathrm{~cm}$ ).

7 The concretion at the surface of the archaeological level results from runoff from the stalagmite located beside the Column Gallery (fig. 4). Two factors explain the differences observed in the structure of the floor: in the concretion sector, the calcite is compact and well crystallized; on the other hand, in the zone linked to the gours, it is crumbly and contains a thin clayey level which appears to result from the decantation of suspension transported particles.

\section{Layer 2: archaeological level - Gravettian (level currently excavated with a thickness of $20 \mathrm{~cm}$ ).}

8 This is a deposit with a closed or semi-open clastic structure. It is made up of blocks, stones and platelet or polyhedral limestone granules and pebbles from endogenous rocks. Burnt and unburned bone shards are abundant and lie flat or in vertical position between the stones. Coarse sands and granules contain abundant burnt bone fragments. Dark red brown sandy silt partially clogs porosity. The whole of the deposit is more or less completely indurate by calcite. 
The topographical position of sector GPA led to the partial leaching of the Gravettian level by water runoff. This phenomenon left abundant debris from burnt bones trapped between coarse elements (limestone stones, bones...). On the other hand, considering the slope and the coarseness of the surface of the deposit, the flow was probably not strong enough to carry and displace the human mandible. Floods in the room may also have affected the archaeological layer. However this hypothesis needs to be reexamined after a comparison of the altitudes of the archaeological layer and the flood level visible on the painted cave wall. The partial cementation of the sediment is post-depositional and corresponds to the preliminary phase of the formation of the overlying stalagmite floor.

Figure 1 - Map showing the location of the main Gravettian sites with human remains in southwestern France.

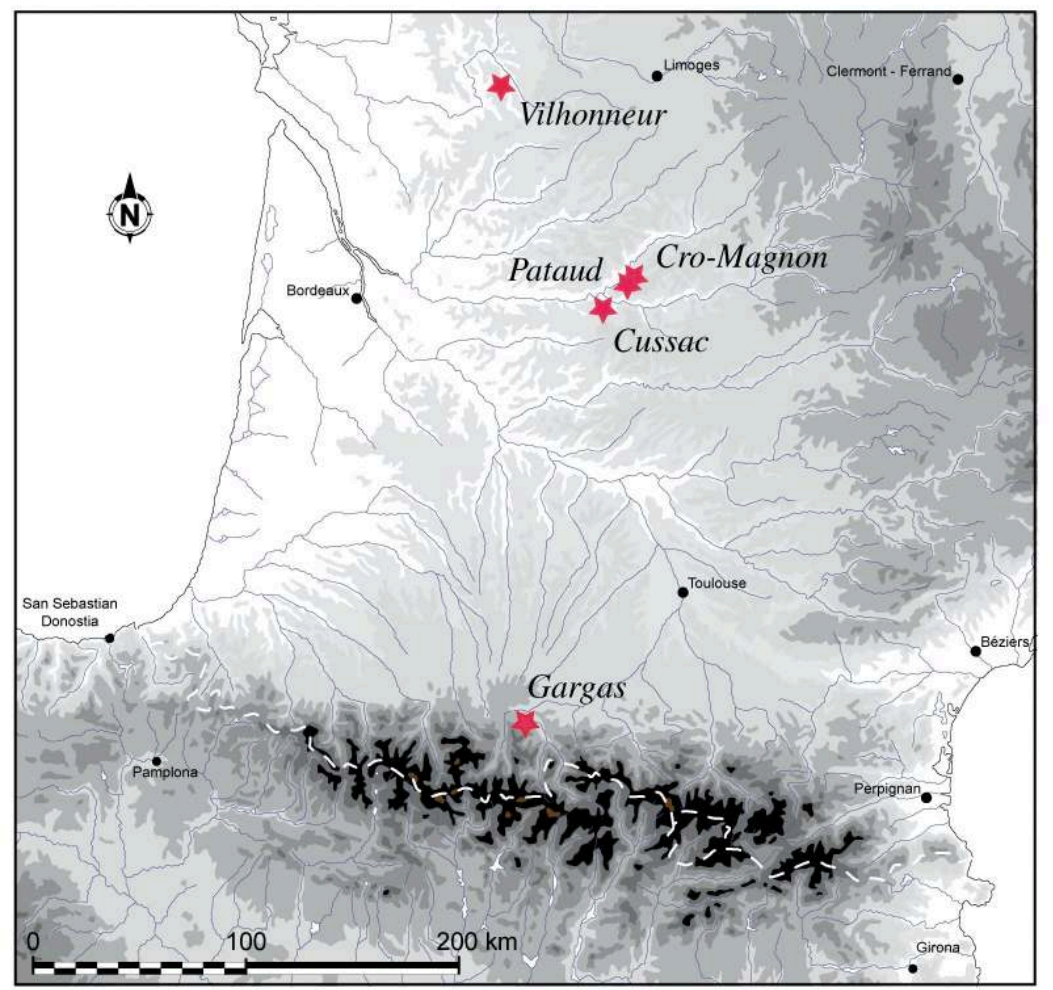

\section{3 - Chrono-stratigraphic context of the mandible}

The mandible was unearthed in the 7th spit of layer 2 (at about $12 \mathrm{~cm}$ under the stalagmite floor) in subsquare $\mathrm{Wb}^{2}$. The left lateral side was oriented $\mathrm{N}-\mathrm{S}$; the left part (body and ramus) was lying flat on a decimetric block and was welded to it by a thin layer of sediment concretion (fig. 5 and 6).

The immediate environment of the mandible is mainly made up of an accumulation of faunal remains (shards of varying sizes and small burnt elements) including some with anthropogenic marks (butchery processing), several lithic elements (tools and debitage products in flint and quartzite), used pebbles and coloring materials. No other human remains were discovered in the $2 \mathrm{~m}^{2}$ excavated zone ${ }^{3}$, apart from a clavicle fragment (n. 
$610 \mathrm{~Wb}$ spit 6bis), discovered in a previous spit slightly higher up, about $30 \mathrm{~cm}$ from the mandible.

For the moment, there is no apparent spatial patterning. There is no combustion structure for example although there are abundant hearth discards made up of burnt bones, charred blocks and pebbles mixed with other remains. This stratigraphic complex appears to correspond to a palimpsest of repeated domestic occupations. Moreover, signs of pigment preparation activities (using iron and manganese oxides) were recorded from the beginning of the excavation onwards.

The attribution of the mandible to the Gravettian is almost certain (fig. 5), given its position in indurate sediment, sealed in a stratigraphic floor and dated by its archaeological context $t^{4}$. The hypothesis of the posterior digging of a pit for burying the young child is not supported here ${ }^{5}$. On one hand, we did not notice any modification of the stalagmite floor overlying the excavated zone (no signs of digging, nor of reworking posterior concretions); and, on the other hand, if it were a burial, it would very probably have contained other human remains.

Figure 2 - Plan of Gargas cave showing the location of painted cave walls and both former and recent excavations (after Barrière 1984; modified by Foucher, Texier 2004).

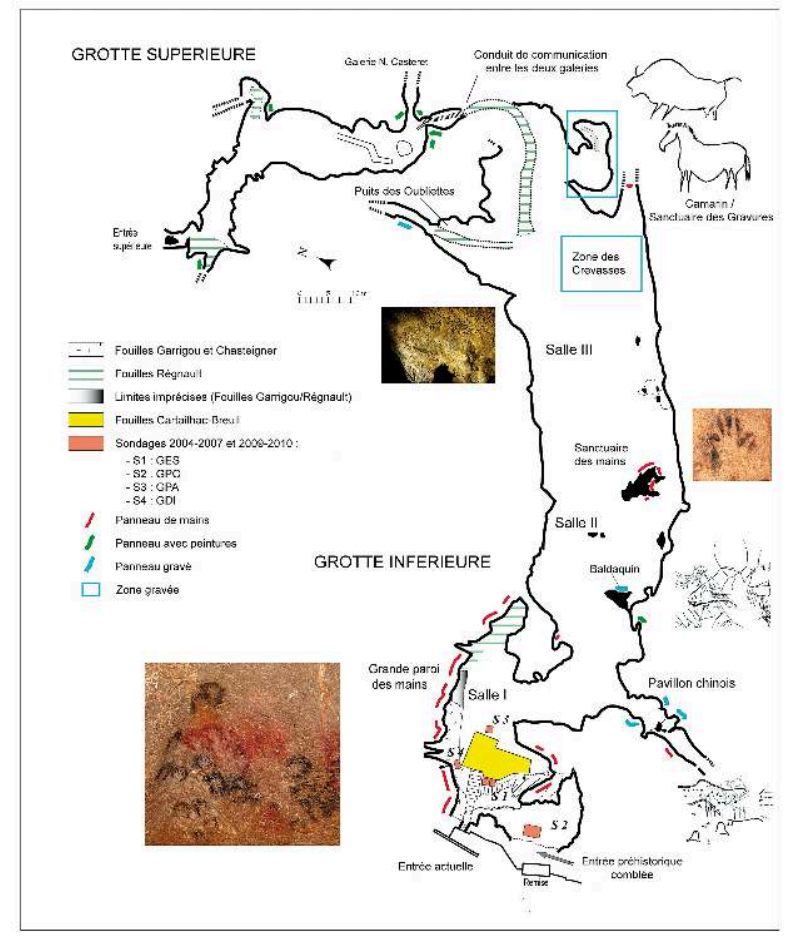

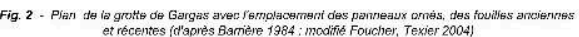


Figure 3 - Location of the GPA excavation survey in Room I - Large hand mural (photo: J.F. Peiré Drac Midi-Pyrénées).

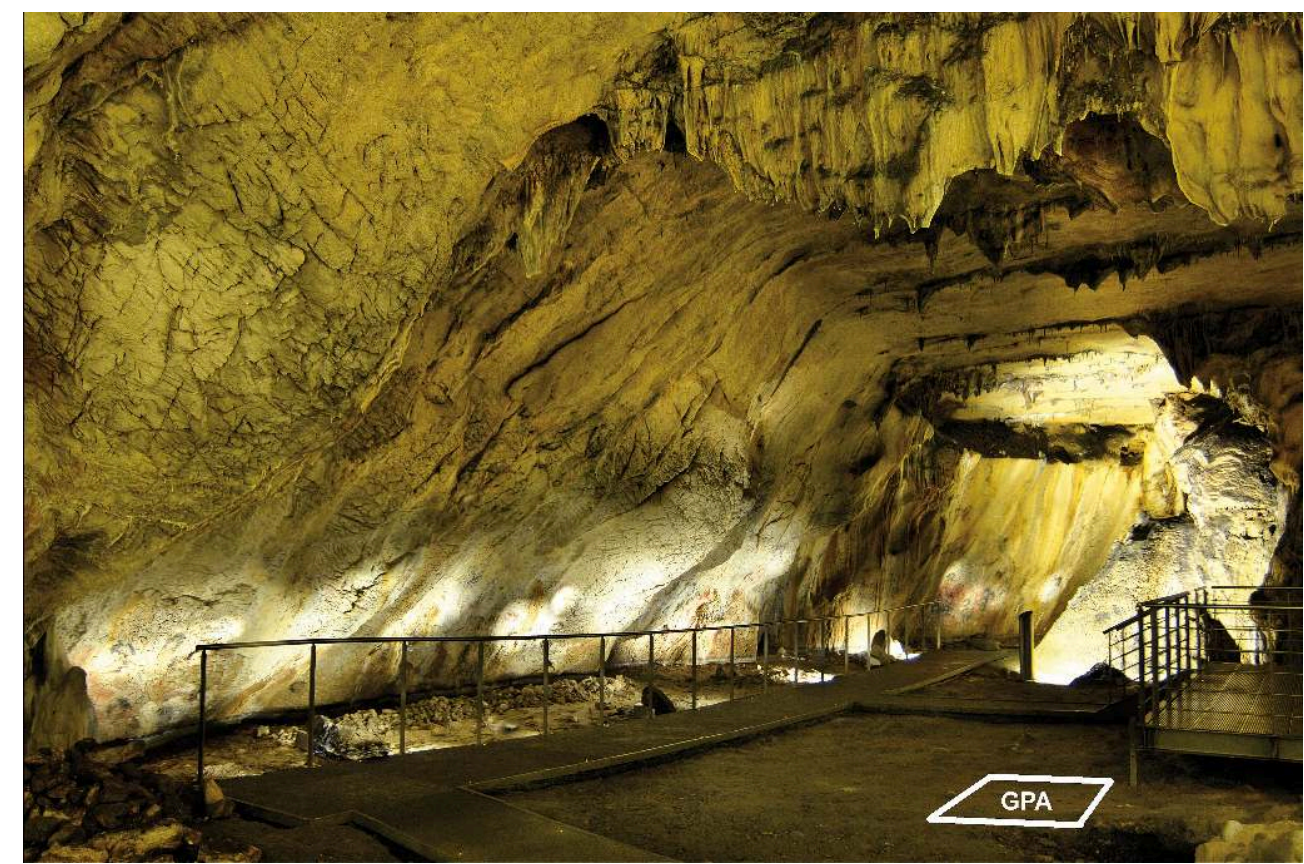

\section{4 - Preliminary description of the mandible}

The mandible was initially left in situ when it was discovered in order to conduct anthropological field observations (photographs, preliminary analyses and descriptions of the immediate context). It was then removed by one of us following the established protocol for DNA research (sterile conditions to avoid any additional contamination: wearing a mask, cap, gloves, use of disinfected tools...). The mandible was wrapped in a sterile environment and kept in an icebox until it was transported to the restoration laboratory Materia Viva (Toulouse, storeroom Délicieux) where it was kept in cold storage. Marie-France Deguilloux (MC-PACEA, University of Bordeaux 1, responsible for DNA studies) took the DNA sample from the lower portion of the right body. The palaeogenomic study is in progress.

This mandible has not yet been separated from the block to which it is joined by concretions. This operation will begin as soon as the acquisition and the segmentation of microtomographic data will be available. Data thus remain preliminary for the moment.

The examination of the mandible in its present state shows that it is the incomplete mandible of a young child (between two and five years old). It is made up of the left part from the symphysis to the mandible ramus (n. 646 a) with no teeth and 2-3 cm of the right portion (n. $646 \mathrm{~b}$ ). The latter is broken at the level of the $\mathrm{dm}_{2} / \mathrm{M}_{1}$ and contains the first lower deciduous molar (fig. 7 and 8). It is separated from the symphyseal region by a crack running from the alveolar side to the lower side (fig. 8). The left condyle seems to be intact. The left coronoid process, the lower side of the angle of the left ramus and the symphyseal region are damaged (fig. 7). 
17 A thin film of concretion covers the surface of the left ramus, part of the left body, the symphysis and all of the preserved alveolar side. Where exposed, the bone does not appear to be degraded (fig. 7 and 8).

On the lateral side and under the angle between the body and the left ramus there is an abnormal swelling, which requires close study (pathological lesion or taphonomic alteration: fig. $7 b)$. No ochre marks are visible on the exposed surface.

Figure 4 - Gargas - GPA locus. The superficial water flows created stepped gours on the gallery floor leading towards the deep part of the cave (a). Moreover, water percolating through ceiling cracks supplies a stalagmite concretion (b), extended by a stalagmite floor (c) covering the Gravettian layer (d). In the area where the former excavations took place, some pieces from the Gravettian layer still remain trapped under strips of the stalagmite floor (e).

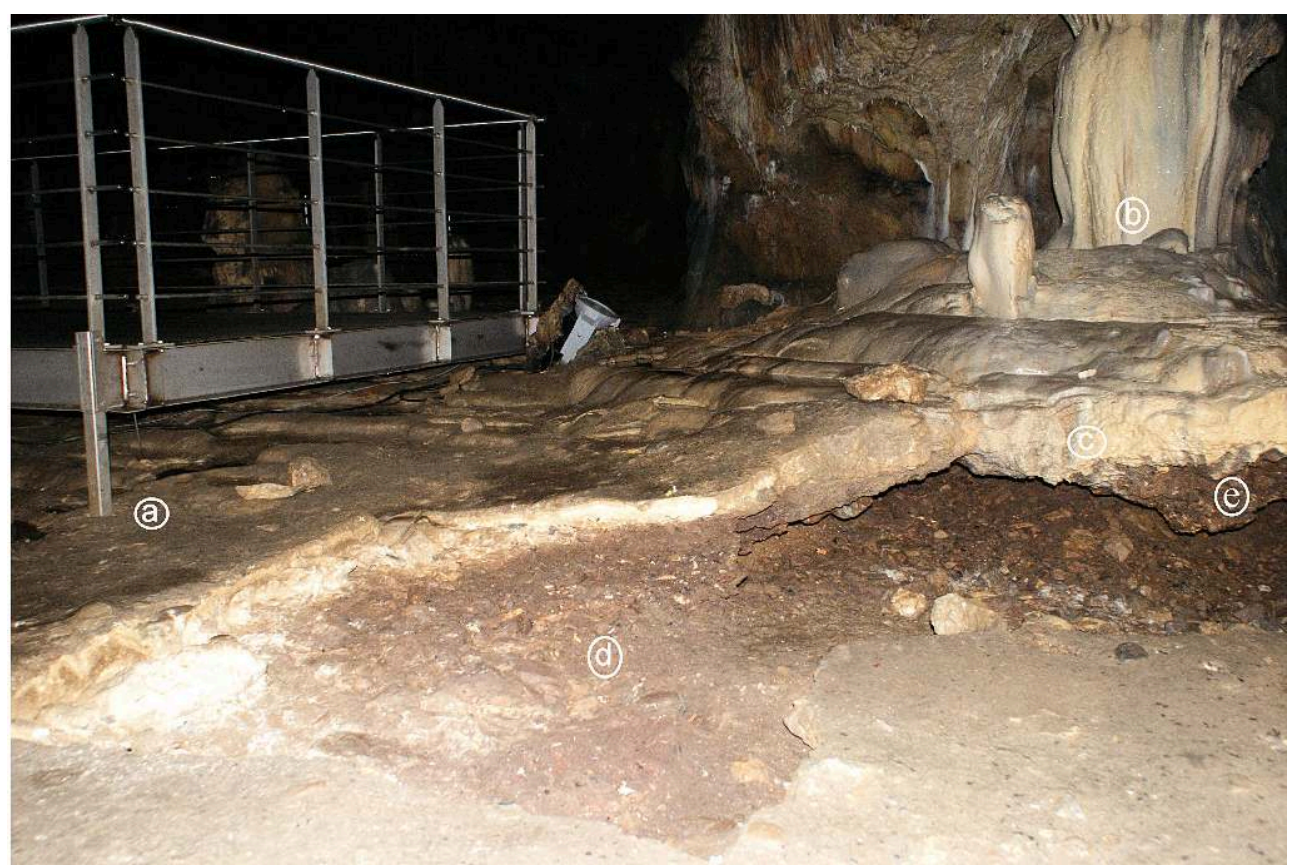


Figure 5 - Gargas - GPA excavation zone. Lithic industry, body ornaments and pebbles used as crushers from the Gravettian occupation.

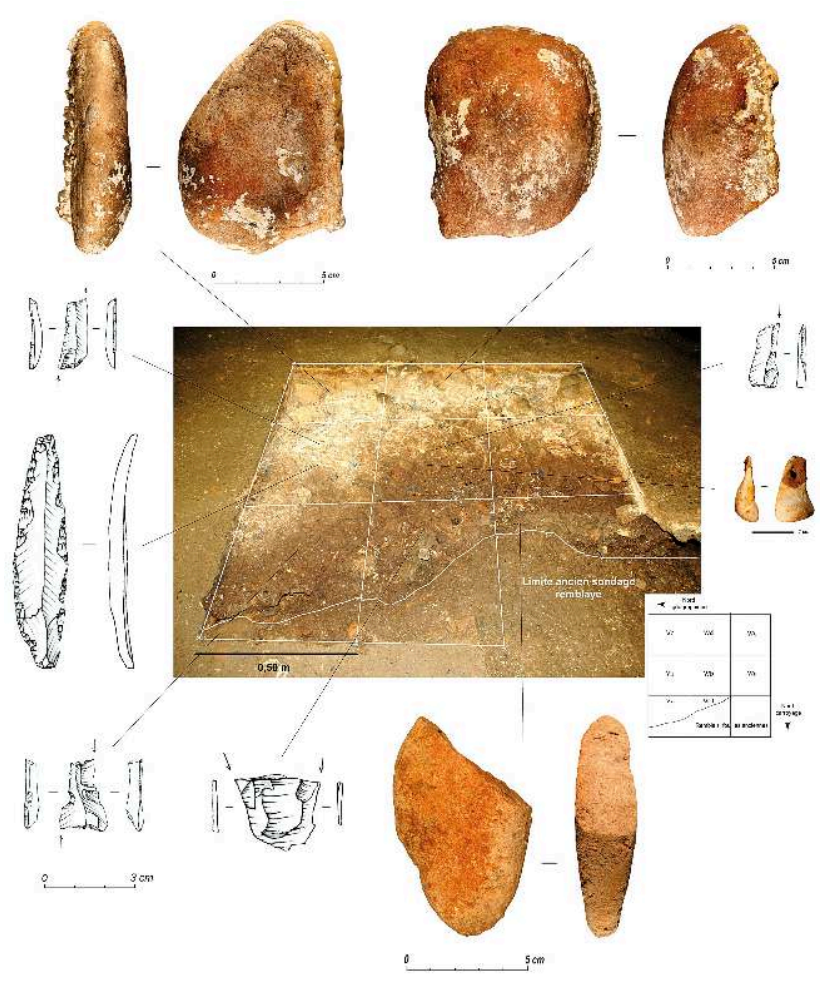

Figure 6 - Gargas - GPA excavation zone (photos: P. Foucher). Square Wb, level 2, spit 7 and detailed view of the mandible n. 646, as it was discovered.

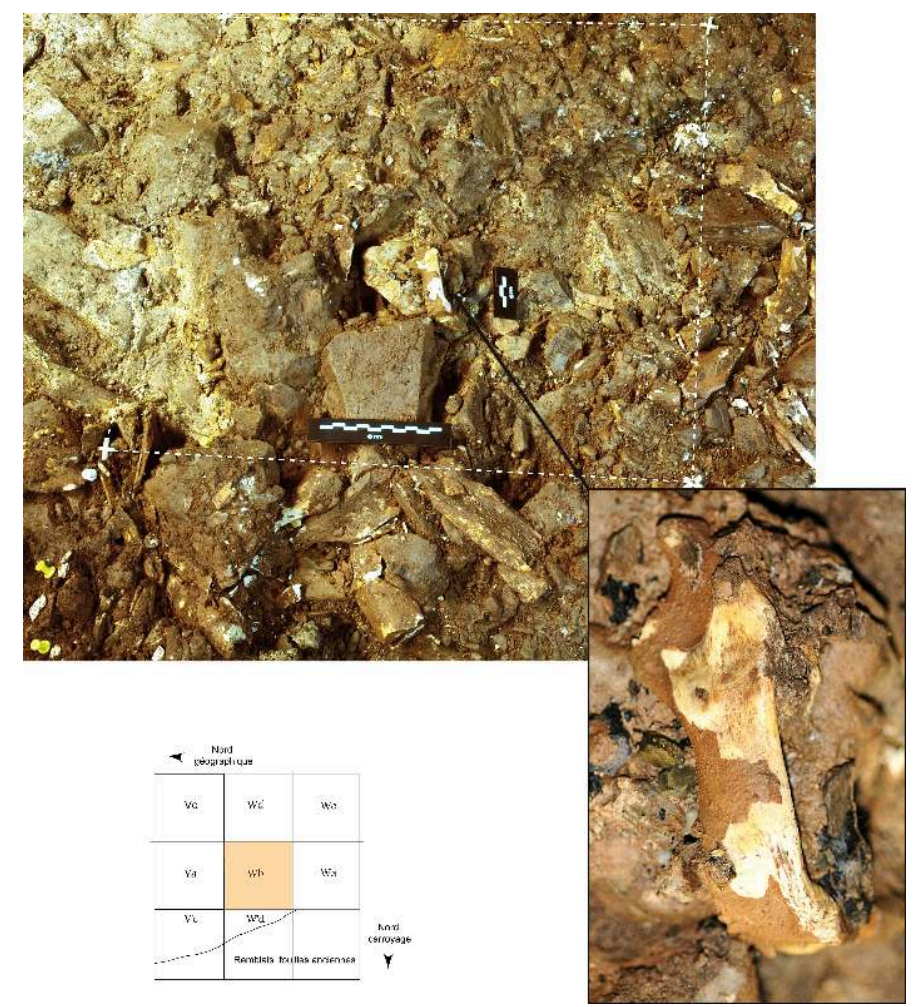


Figure 7 - Gargas - GPA locus - Square Wb: level 2, spit 7 (photos: D. Henry-Gambier and P. Foucher). (a) Close up view of the mandible (n. 646 a). 1: symphysis. 2: condyle. 3: location of a possible anomaly on the left body; (b) Close up view of the anomaly.
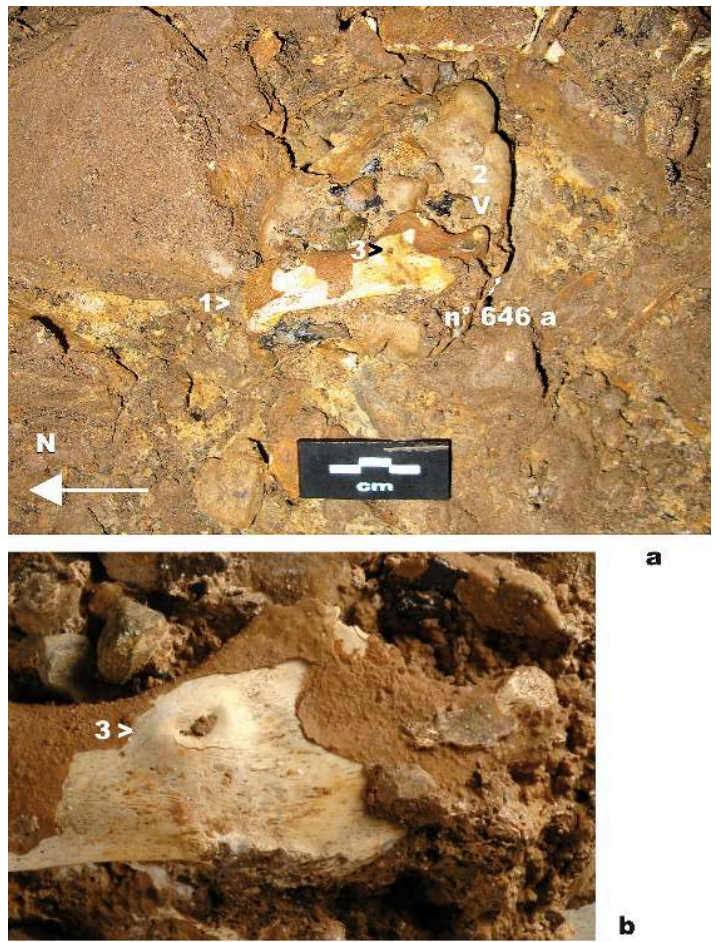

Figure 8 - Gargas - GPA locus - Square Wb: level 2, spit 7 (photos: D. Henry-Gambier). Front view of the mandible. 1: crack dividing the mandible into two fragments. 2: symphysis.

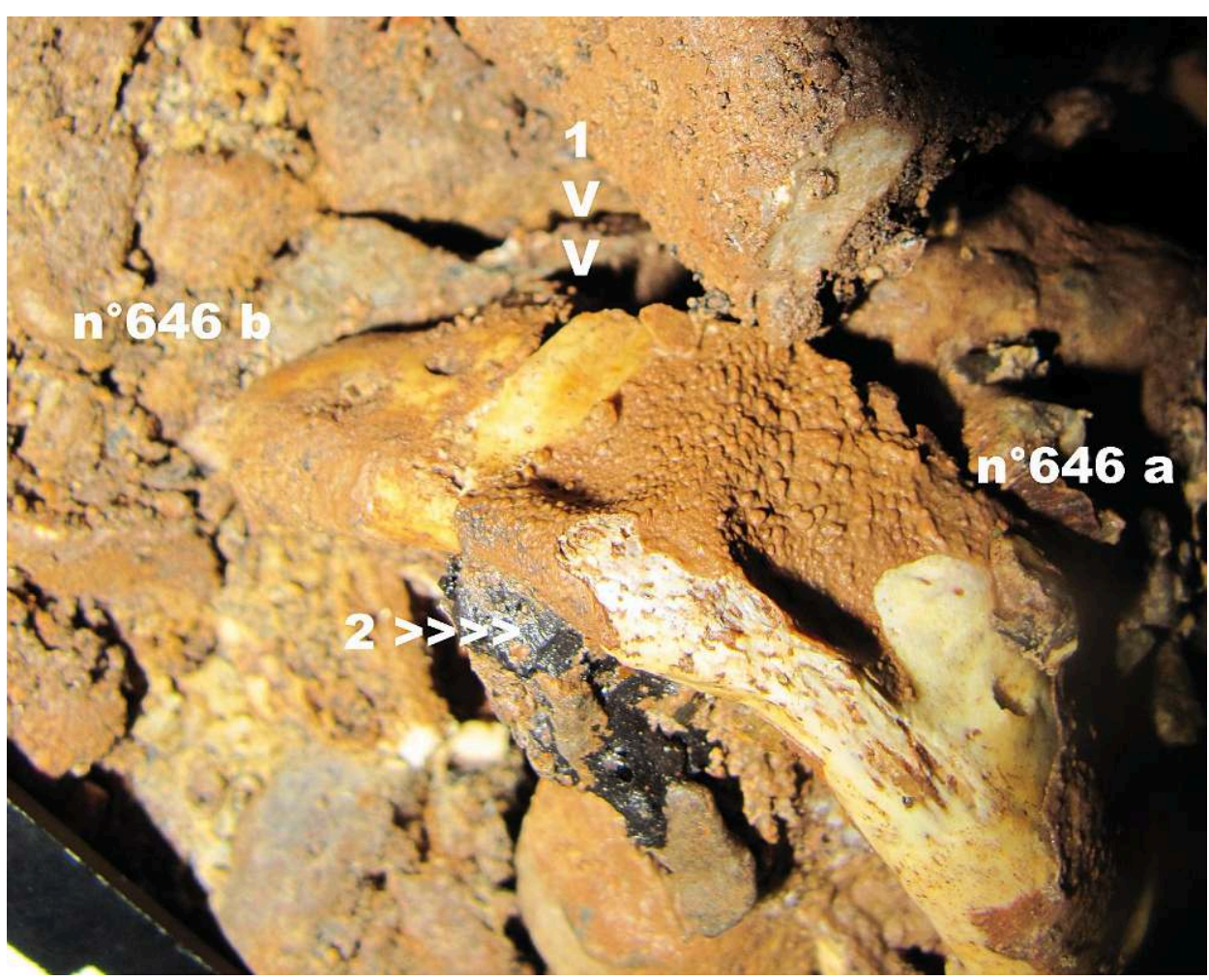




\section{5 - Scientific interest of the discovered remains}

In the present state of research this human remain is an isolated find, as is often the case in Upper Palaeolithic contexts, regardless of the associated technocomplex. However, this discovery is important for several reasons:

1. The lower Gargas gallery had not yielded any human remains up until the present, apart from a femur fragment reported by Obermaier (1925) and again by Vallois and Movius (1952). However the localization of this fragment is unknown.

2. The stratigraphic position of this mandible implies that it belongs to the Gravettian with Noailles burins. It thus enlarges the rather scant corpus of human remains for this period, for which Isturitz cave (Pyrénées-Atlantiques) is the only Pyrenean site to have yielded several remains in a contemporary chronocultural context (sensu lato). Overall, there are only four Gravettian sites in France with significant human remains (relatively well preserved skeletons) (fig. 1): Cro-Magnon, Cussac and Pataud in Dordogne, Vilhonneur in Charente. Elsewhere, discoveries consist of rare isolated teeth or small bone fragments, which provide little information (Henry-Gambier et al. 2007; Henry-Gambier 2008; HenryGambier et al. in press a and b). The Gargas mandible is sufficiently well preserved to bring new data (palaeogenetic and morphometric) concerning Gravettian populations and particularly young children (Henry-Gambier 2001).

3. Current data indicate that this mandible is not in primary position. It is imperative to continue the analysis of the surface of this piece (to look for degradations and alterations ${ }^{6}$ ), to pursue the geological study of the level as it appears from the test excavation, as well as the other archaeological data in order to discuss the significance of these remains and the reasons for their presence in layer 2. Ongoing investigations should allow us to determine whether this mandible comes from the natural or anthropic dismantling of a burial, or whether is it just an isolated remain. In the latter case, what sort of behavior does it signify?

Indeed, it is important to recall that burial is the most widely documented funerary practice for the European Gravettian and that most of the human remains were discovered in a sepulchral context (Henry-Gambier 2008). In France, without divulging details of ongoing studies, it appears that the context and characteristics of the human remains at Cro-Magnon, Cussac, Pataud and Vilhonneur are different from those described for the rest of Europe (Aujoulat et al. 2002; Henry-Gambier et al. 2007; HenryGambier et al. in press a and b). In other words, for the time being at least, burial does not appear to be a common Gravettian practice in France. Moreover, at three of these sites (Cussac, Vilhonneur and Pataud), human remains are associated with rock art (Henry-Gambier et al. in press a and b).

In Vilhonneur Cave, the cave wall themes are limited and located in the same room as the human skeleton (Henry-Gambier et al. 2007). However, further investigation is required in order to establish a possible relation between the skeleton and the paintings.

At Cussac, the three loci containing the human remains of at least six individuals are located in the lower gallery, as are most of the engravings. But none of these loci is in direct relation with an engraving (Aujoulat et al. 2002; Henry-Gambier et al. in press a). However, like at Vilhonneur, no archaeological excavation of the funerary deposits has been conducted, and it is impossible for the moment to evaluate the links between the human bones and the cave wall art. 
At Gargas, the analysis of the decorated cave walls makes it possible to distinguish two cave wall complexes, from both a chronological and thematic point of view; the upper gallery and the lower gallery. The latter presents marked topographic structure depending on the type of artistic representation (handprints, engraved animals, finger drawings), and has been attributed to the Gravettian on the basis of the archaeological context (Clottes et al. 1992; Foucher et al. 2007; 2008a). It is important to point out that Room I, near the prehistoric entrance, contains two thirds of the Gargas handprints and hosted a vast occupation area between 28,000 and 25,000 BP (Foucher et al. 2011). Recent research on these occupations indicates that diverse activities took place here, most of which were linked to the demands of daily life: manufacture of tools, hunting projectiles and body ornaments, processing animal skins, butchery activities and reusing animal carcasses for non-alimentary purposes (Foucher, San Juan-Foucher dir. 2011; Foucher et al. 2008b, 2012). We can thus distinguish a "domestic" area and a "symbolic" area, regrouped together in the same place (Room I). This is the context in which the child's mandible was found. While waiting for the results of additional studies (palaeogenomics, classic morphometry and taphonomy), this new discovery brings an additional component to future study perspectives and to the interpretation of the Gargas site.

It is also important to note that even if Cussac, Pataud or Vilhonneur contain more human remains, the Gargas mandible is a new, additional example of human remains found in a decorated cave context

The recent French discoveries thus lead to the opening of a new chapter on investigating the links between mortuary practices and rock art, even though each of these sites presents different cave wall contexts and spatial configurations, which must be taken into account for interpretations. These discoveries will undoubtedly contribute to enhancing our knowledge of mortuary behavior in the Gravettian culture, notably in the southwest of Europe.

The ongoing research in Gargas cave is part of a multi-year programmed operation funded by the Ministry for Culture and Communication, the DRAC-Midi-Pyrénées, with the support of the Hautes-Pyrénées General Council. The association Archéologies is also a partner of this operation. We wish to thank the municipality of Aventignan, owner of the cave, for logistic support and assisting our project.

\section{BIBLIOGRAPHY}

AUJOULAT N., GENESTE J.-M., ARCHAMBEAU Ch., BARRAUD D., DELLUC M., DUDAY H., HENRYGAMBIER D. 2002 - La grotte ornée de Cussac - Le Buisson-de-Cadouin (Dordogne) : premières observations. Bulletin de la Société Préhistorique Française, 99 (1), p. 129-137.

BOULESTIN B. 1999 - Approche taphonomique des restes humains. Le cas des Mésolithiques de la grotte des Perrats et le problème du cannibalisme en préhistoire récente européenne. Oxford : Archaeopress (BAR International Series, 776), $276 \mathrm{p}$. 
BREUIL H., CHEYNIER A. 1958 - Les fouilles de Breuil et Cartailhac dans la grotte de Gargas en 1911 et 1913. Bulletin de la Société méridionale de spéléologie et de préhistoire, V, 1954-55, p. 341-382 (extract from Bulletin de la Société d'histoire naturelle de Toulouse, 1958, 93).

CLOTTES J., VALLADAS, H. CACHIER, H., ARNOLD, M. 1992 - Des dates pour Niaux et Gargas. Bulletin de la Société Préhistorique Française, 89 (9), p. 270-274.

FOUCHER P. 2004 - Les industries lithiques du complexe Gravettien-Solutréen dans les Pyrénées. Technotypologie et circulation des matières siliceuses de part et d'autre de l'axe Pyrénées-Cantabres. Thèse de l'Université de Toulouse 2-le-Mirail, 3 vol., 647 p.

FOUCHER P. 2006 - Gargas et l'Atlantique : les relations transpyrénéennes au cours du Gravettien. In : Homenaje al Prof. Jesús Altuna. Munibe, 57, 2005-2006, tome II : Arqueología, p. 131-147.

FOUCHER P. à paraître - Synthèse chrono-culturelle sur le Gravettien des Pyrénées : constat et réflexions sur la stabilité régionale des traditions techniques. In : El Gravetiense cantábrico, octobre 2011, Museo de Altamira.

FOUCHER P., SAN JUAN-FOUCHER C. (dir.), avec la coll. de ANGÁS PAJAS J., FERRIER C., M.-F. DEGUILLOUX, DRIEUX-DAGUERRE M., D. HENRY-GAMBIER, IRIARTE CHIAPUSO M.-J., MIRANDA OLIVÁN J., MOURRE V., PEYROUX M., POPLIN F., OBERLIN Ch., QUEFFELEC A., SÉRONIE-VIVIEN M.-R., SERVELLE Ch., VERCOUTÈRE C. 2011. - La grotte de Gargas (Aventignan, Hautes-Pyrénées) : rapport de synthèse de fouille programmée (triennale 2009-2011). Toulouse : Service Régional de l'Archéologie de Midi-Pyrénées, 185 p.

FOUCHER P., SAN JUAN-FOUCHER C., OBERLIN C. 2011 - Les niveaux d'occupation gravettiens de Gargas (Hautes-Pyrénées) : nouvelles données chronostratigraphiques. In : N. Goutas, L. Klaric, D. Pesesse, P. Guillermin (dir.), À la recherche des identités gravettiennes : actualités, questionnements et perspectives. Actes de la table ronde sur le Gravettien en France et dans les pays limitrophes, Aixen-Provence, 6-8 octobre 2008, Éd. Société préhistorique française, p. 373-385 (Mémoire LII).

FOUCHER P., SAN JUAN-FOUCHER C., RUMEAU Y. 2007 - La grotte de Gargas. Un siècle de recherches. Communauté de communes du canton de Saint-Laurent-de-Neste, $126 \mathrm{p}$.

FOUCHER P., SAN JUAN-FOUCHER C., RUMEAU Y. 2008a - La grotte de Gargas : un sanctuaire préhistorique au cœur des Pyrénées. Archéologia, 459 (oct.), p. 44-51.

FOUCHER P., SAN JUAN C., SACCHI D., ARRIZABALAGA A. 2008b - Le Gravettien des Pyrénées. In : Le Gravettien : entités régionales d'une paléoculture européenne. Actes du colloque des Eyzies, juillet, 2004, Paleo, 20, p. 331-356.

FOUCHER P., SAN JUAN-FOUCHER C., VERCOUTÈRE C., FERRIER C. 2012 - La grotte de Gargas (Hautes-Pyrénées, France) : l'apport du contexte archéologique à l'interprétation de l'art pariétal. In : J. Clottes (dir), L'art pléistocène dans le monde / Pleistocene art of the world / Arte pleistoceno en el mundo. Actes du Congrès IFRAO, Tarascon-sur-Ariège, 6-11 septembre 2010. $\mathrm{N}^{\circ}$ spécial de Préhistoire, Art et Sociétés, Bulletin de la Société Préhistorique Ariège-Pyrénées, LXV-LXVI, 2010-2011, livre : p. 52-53 et CD : p. 209-225.

FOUCHER P., SAN JUAN-FOUCHER C., FERRIER C., COUCHOUD I., VERCOUTÈRE C. 2008c - La grotte de Gargas (Aventignan, Hautes-Pyrénées) : nouvelles perspectives de recherche et premiers résultats sur les occupations gravettiennes. In : J. Jaubert, J.-G. Bordes, I. Ortega (dir.), Les sociétés paléolithiques d'un grand Sud-Ouest - Nouveaux gisements, nouvelles méthodes, nouveaux résultats. Actes des journées de la Société préhistorique française et de l'Université de Bordeaux I, nov. 2006, p. 301-324 (Mémoire de la Société préhistorique française, 47).

FOUCHER P., VALLADAS H., TISNERAT N., DUDAY H., GACHINA J. 1995 - Le squelette réputé aurignacien de la grotte du Bouil Bleu à la Roche Courbon (Saint-Porchaire, Charente-Maritime) : révision de l'âge- 
datation directe par la méthode du carbone 14 (S.M.A.). Bulletin de la Société préhistorique française, $92(4)$, p. 443-444.

HENRY-GAMBIER D. 2001 - Les enfants de Grimaldi (Grotte des Enfants site des Baoussé - Roussé, Italie). Anthropologie et Palethnologie funéraire. CTHS/RMN. 250 p.

HENRY-GAMBIER D. 2008 - Pratiques funéraires et comportements des populations gravettiennes en Europe : bilan des données et interprétations. Paléo, 20, p. 399-438.

HENRY-GAMBIER D., BEAUVAL C., AIRVAUX J., AUJOULAT N., BARATIN J.F., BUISSON-CATIL J. 2007 - New hominid remains associated with gravettian parietal art (Les Garennes, Vilhonneur, France). Journal of Human Evolution, 53 (6), p. 747-750.

HENRY-GAMBIER D., COURTAUD P., DUDAY H., DUTAILLY B., VILLOTTE S., DEGUILLOUX MF., PÉMONGE MH., AUJOULAT N., DELLUC M., FOURMENT N., JAUBERT J. sous-presse (a) - Grotte de Cussac (Le Buisson-de-Cadouin) : un exemple de comportement original pour le Gravettien. Acte du Congrès de la SPF - Les-Eyzies- de Tayac (Dordogne) juin 2010.

HENRY-GAMBIER D., VILLOTTE S., BEAUVAL C., BRUZEK J., GRIMAUD-HERVÉ D. sous-presse (b) Les vestiges humains : un assemblage original In Le Gravettien final de l'abri Pataud (Dordogne, France) Fouilles et études 2005 - 2009 R. Nespoulet, L. Chiotti, D. Henry - Gambier (Dir) BAR International Series XXXX, 2012 p. 135 - 176.

OBERMAIER H. 1925 - El hombre fósil. Madrid : Museo de Ciencias naturales, 2e Ed. Comisión de Investigaciones paleontológicas y prehistóricas, 457 p. (Memoria 9).

SAN JUAN-FOUCHER C. 2011 - Industrie osseuse décorée et parures gravettiennes de Gargas (Hautes-Pyrénées, France) : marqueurs culturels, sociaux et territoriaux. In : N. Goutas, L. Klaric, D. Pesesse, P. Guillermin (dir.), À la recherche des identités gravettiennes : actualités, questionnements et perspectives. Actes de la table ronde sur le Gravettien en France et dans les pays limitrophes, Aix-en-Provence, 6-8 octobre 2008, Éd. Société préhistorique française, p. 225-241 (Mémoire LII).

SAN JUAN-FOUCHER C. à paraître - Industria ósea decorada y arte mueble del gravetiense pirenaico : perspectivas territoriales actualizadas. In : El Gravetiense cantábrico, octobre 2011, Museo de Altamira.

VALLOIS H.V., MOVIUS H.L. 1952 - Catalogue des hommes fossiles. In : XIXe congrès géologique international, Alger, fasc. V, $378 \mathrm{p}$.

\section{NOTES}

1. For a complete history of research in the cave, see Foucher 2004 and Foucher et al. 2007.

2. The mandible was discovered in the afternoon on Friday 16th September and bears the inventory number: GPA-11-Wb-646.

3. The bone material from the surfaces 6 bis and 7 was totally revised by D. H.-G. and C. V.

4. The lithic material contained Noailles burins in all successive layers (1 to 7).

5. This is a well-known case in the Bouil Bleu cave in the Roche Courbon (Saint-Porchaire, Charente maritime): cf. Foucher et al. 1995.

6. Degradation: set of processes entailing deterioration or even destruction, which tend to mask or suppress information. Alteration: modification which transforms bone in relation to its normal state and which generates information. Alteration is generally quite limited and does not affect bone properties. (Boulestin 1999 - p. 45). 


\section{ABSTRACTS}

New archaeological research has been carried out in the lower gallery of Gargas cave (HautesPyrénées) since 2004. The main results concern the Gravettian occupations of this gallery and update data from former excavations directed by Cartailhac and Breuil (1911-1913), in particular, data relating to the functional, spatial and chronological characteristics of site use by the authors of the rock art. During the 2011 excavations, a young child's mandible was discovered in the upper part of the Gravettian level of Room I, where two thirds of the painted hands are located. The aim of this paper is to present this discovery with a preliminary description of the mandible and its stratigraphic location. The interest of these human remains is evaluated in regard to the context of recent discoveries in Cussac and Vilhonneur and updated data for southwestern Europe. The possible existence of a funerary context in Gargas cave could advance further studies and interpretations for this key European Gravettian site.

\section{INDEX}

Keywords: Gravettian, Homo sapiens sapiens, Pyrenees

\section{AUTHORS}

\section{PASCAL FOUCHER}

Service Régional de l'Archéologie - DRAC Midi-Pyrénées, rue de la Dalbade, 31000 Toulouse et UMR 5608 TRACES - Université de Toulouse-le-Mirail, 5 allées Antonio Machado, 31000 Toulouse, France - cristina.sanjuan@culture.gouv.fr ;pascal.foucher@culture.gouv.fr

\section{CRISTINA SAN JUAN-FOUCHER}

Service Régional de l'Archéologie - DRAC Midi-Pyrénées, rue de la Dalbade, 31000 Toulouse et UMR 5608 TRACES - Université de Toulouse-le-Mirail, 5 allées Antonio Machado, 31000 Toulouse, France - cristina.sanjuan@culture.gouv.fr ;pascal.foucher@culture.gouv.fr

\section{DOMINIQUE HENRY-GAMBIER}

CNRS, PACEA/A3P, UMR 5199, avenue des Facultés, 33405 Talence cedex, France -

d.gambier@pacea.u-bordeaux1.fr

\section{CAROLE VERCOUTÈRE}

UMR 7194, Département de Préhistoire, Muséum national d'Histoire naturelle,Paris, France cvercout@mnhn.fr

\section{CATHERINE FERRIER}

Université de Bordeaux, PACEA/PPP, UMR 5199, avenue des Facultés, 33405 Talence cedex, France - c.ferrier@ipgq.u-bordeaux1.fr 